\title{
The Effect of Tillage on Soil Moisture Conservation: A Review
}

\author{
Demsew Bekele* \\ Fogera National Rice Research and Training Center (FNRRTC) Ethiopian Institute of Agricultural Research \\ (EIAR), Addis Ababa, Ethiopia, Bahir Dar, Ethiopia. \\ *Corresponding Authors: Demsew Bekele, Fogera National Rice Research and Training Center \\ (FNRRTC) Ethiopian Institute of Agricultural Research (EIAR), Addis Ababa , Ethiopia, Bahir Dar , \\ Ethiopia.
}

\begin{abstract}
Soil tillage systems can be able to influence soil compaction, water dynamics and crop yield. These processes can be expressed as changes of soil microbiological activity, soil respiration and sustainability of agriculture. The objective of this paper is to review the effects of tillage practices on soil moisture conservation. Tillage affects soil physical properties (bulk density and infiltration rate) and by measuring changes in soil water holding capacity in comparison with controlled plot. zero tillage with $20 \%$ residue retention was found to be suitable for soil health and achieving optimum yield. The MT and NT applications reduce mobilization of soil. Soil moisture was higher in NT and MT at the time of sowing and in the early stages of vegetation. Conservation tillage is commonly used in regions affected by water and wind erosion. Tillage treatments directly or indirectly influence soil hydraulic properties such as water infiltration, hydraulic conductivity, and water retention which determine the ability of the soil to capture and store water through precipitation or irrigation. Tillage have also its own positive and negative influence on residue incorporation conserved moisture in the soil and other soil properties like, soil PH, soil organisms, water holding capacity, soil structure and bulk density.
\end{abstract}

Keywords: Minimum tillage, no-tillage, soil respiration, yield, Conservation tillage.

\section{INTRODUCTION}

Agricultural production in the arid and semi-arid areas are highly dependent on rainfall because water for irrigation is scarce or farmers cannot afford the technology. In order to have successful rainfed crop production in such areas, rain water conservation is essential (Barron et al., 2003). The success of onfram soil water conservation however depends upon many soil factors such as soil bulk density, porosity, soil surface sealing and crusting, surface roughness, hardpans, hydraulic conductivity, and infiltration rates as they determine the hydrological properties of soil (Strudley et al., 2008).

Soil erosion is sensitive to the importance of the soil structure is quite large. Silt and fine sand content in the soil, the higher, the greater is the potential credibility. Silt and sand contents of soil were high. As reported soil erosion rate sensitivity increases with sand and silt soil given that the erosion risk is present in the region investigated is evident. Results showed that physical and chemical analysis of soil, the value of this land is in high alkaline calcium content are very high and Nitrogen $(\mathrm{N})$ is seen to be deficient. In addition, to increase the soil's water holding capacity, as well as holding both nutrients play an important role in aggregate stability is very low in organic matter clearly. In this way the use of climatic factors and soil, as well as stubble burning in these lands and use of organic fertilizers in the region plays a major role in the widespread absence. It also triggered soil erosion and soil fertility decline is caused. Calcium, magnesium, phosphate, and potassium contents of soil are observed to be higher (Meryem and Funda, 2015).

Tillage affects soil physical properties (bulk density and infiltration rate) and by measuring changes in soil water holding capacity in comparison with controlled plots. Since crop yield is highly affected by soil density and soil-water hydraulic properties, the results will help on the decision of the type of tillage treatment that should be used to reduce yield loss due to soil compaction on some Jordanian soils under field conditions (Abu Hamdeh, 2004).

Tillage is one of the fundamental practices of agricultural management. It is the procedure by which man disturbs, overturns and rearranges the soil to create favorable soil physical conditions for crop 
growth. The tillage operation loosens, granulate, crush, and even compact the soil practices. The importance of the land in agricultural production processing topics, manufacturers, increases productivity with timely and accurate processing of applications on soil. In addition to the increase in the efficiency of handling soil erosion by the soil protection and control of soil water contents are benefits such as to conservation. In this study, tillage, reduced tillage in dry farming areas, mulching and soil moisture content will rely upon (Meryem and Funda, 2015).

Soil sustainability will play a key role in maintaining crop production in the face of decreased precipitation due to global climate change. Soil water content was not increased by use of reduced tillage or cover crops when compared to fields that had not used conservation practices. In tillage practice SOC and moisture retention on prospects for management to improve soil water holding capacity. Not cultivating soil, rotating crops over the years, and leaving crop residues on the surface in the practice of zero tillage/conservation agriculture reverses the historically accelerating degradation of soil organic matter (SOM) and soil structure, while increasing soil biological activity (Landers et al., 2013 and Chawala \& Kahlon, 2018).

Erosion is a natural event cannot be prevented. Every moment, everywhere is an ongoing process. This process can be seen with the naked eye such as sizes that can last for centuries that can influence can be observed in a few years. In order to protect the existing soil and grass plants such as trees should be planted in soil. Trees and herbaceous plants, reducing the effects of wind and rain erosion, provide less effective realization (Meryem and Funda, 2015).

\subsection{Objective}

The main objective of this paper is to review the effects of tillage practices on soil moisture conservation.

\section{Methodology}

This review paper was taken from different literatures, books, websites and scientific journals which are related to tillage practices on soil moisture conservation.

\section{Materials AND Methods}

\subsection{Description of Tillage}

Tillage is the manipulation of the soil in to a desired condition by mechanical means: tools are employed to achieve some desired effect (such as pulverization, cutting or movement). Soil is tilled to change its structure, to kill weeds, and to manage crop residues. Soil-structure modification is often necessary. Farming systems today have more obvious and detectable social, ecological, economic and environmental implications than ever before because of the growing concerns about agricultural sustainability and the environment. Tillage, basic \& important component of agricultural production technology influences agricultural sustainability through its effects on soil processes, properties and crop growth (Khursheed et al., 2019).

Tillage has been an integral component of crop production systems since the beginning of agriculture. The process of tilling or preparing the soil was greatly refined with the invention of the first plow by the Chinese in the sixth century b.c., and since then, various types of tillage equipment and systems have been developed for seedbed preparation and cultivation (Mitchell et al., 2009).

Conservation tillage systems that reduce or combine passes do so generally with relatively high amounts of soil disturbance, and therefore do not protect the soil resource as well as do the no-tillage or striptillage approaches (Mitchell,J.P , et al. ,2009). no-tillage or direct seeding systems, the soil is left undisturbed from harvest to planting except perhaps for injection of fertilizers (Gesellschaftfiir, et al, 2003).

\subsection{Effect of Different Tillage Practice on Soil Moisture Conservation}

\subsubsection{Zero tillage practice}

According to Monneveux et al.,(2006) The effects of zero tillage and residue conservation in continuous maize-cropping vary highly with climatic conditions and nitrogen availability. In the present study, maize was cultivated during the wet and dry seasons in central Mexico for three consecutive years, under different treatments combining tillage with residue management techniques and with nitrogen 
rates. In some treatments, maize was also intercropped with jackbean, Canavalia ensiformis L. (DC). Yield and yield components as well as physiological traits and soil characteristics were assessed during the wet and dry seasons for the third year of cultivation. During the wet season, zero tillage was associated with less biomass and grain yield. Leaf chlorophyll concentration was smaller under zero tillage, suggesting less nitrogen uptake. Both zero tillage and residue conservation reduced early growth and strongly increased ear rot. During the dry season, zero tillage was associated with greater root mass, as measured by electrical capacitance. Residue conservation decreased the anthesis silking interval, suggesting better water uptake. There was, however, no significant effect of tillage or residue management practices on yield. Zero tillage was found to be associated with increased soil bulk density, nitrogen concentration and microbial biomass organic carbon. Residue conservation increased soil carbon concentration as well as microbial biomass organic carbon. Intercropping with jackbean and conservation of its residues in addition to maize residues increased soil nitrogen concentration. Further Investigation may provide more information on the factors related to zero tillage and residue conservation that affect maize early growth, and determine to which extent the observed modifications of soil chemical and physical properties induced by conservation tillage will further affect maize yield

According to Alam K. et al. (2014) cropping cycles required to improve OM status in soil and to investigate the effects of medium- term tillage practices on soil properties and crop yields in Grey Terrace soil of Bangladesh under wheat-mung bean cropping system. Four different tillage practices, namely, zero tillage (ZT), minimum tillage (MT), conventional tillage (CT), and deep tillage (DT), were studied in a randomized complete block (RCB) design with four replications. Tillage practices showed positive effects on soil properties and crop yields. After four cropping cycles, the highest $\mathrm{OM}$ accumulation, the maximum root mass density $(0-15 \mathrm{~cm}$ soil depth), and the improved physical and chemical properties were recorded in the conservational tillage practices. Bulk and particle densities were decreased due to tillage practices, having the highest reduction of these properties and the highest increase of porosity and field capacity in zero tillage. The highest total $\mathrm{N}, \mathrm{P}, \mathrm{K}$, and $\mathrm{S}$ in their available forms were recorded in zero tillage. All tillage practices showed similar yield after four years of cropping cycles. Therefore, zero tillage with $20 \%$ residue retention was found to be suitable for soil health and achieving optimum yield under the cropping system in Grey Terrace soil.

Acording to J.K. Ward, et al, (2013) The cover crop was killed chemically before planting of cash crop and managed with a roller-crimper. Yield, soil moisture, leaf temperature, cover crop biomass, and cover crop chemical analysis data were collected. Results from the first two years of this study indicate that winter cover crops have negatively impacted crop yields, potentially due to Nitrogen availability in the soil. Spring tillage significantly increased cash crop yields. Fall tillage was not significantly different from no-till due to soil reconsolidation. As work continues on this study the results should indicate which tillage and cover crop systems increase soil quality, productivity, and profitability in these degraded soils.

According to Dangolani et al, (2013) The effect of four types of tillage operations on soil moisture and morphology and performance of three varieties of cottonat Tajik Agrarian University. the effect of four types of tillage operations on the performance of three varieties of cotton in a split-plot design in randomized complete block design in the Cotton Research Institute of Hashemabad Agricultural Station. The results of three years of experiment suggest the significance of performance and performance components, where low-till cultivation leads to $695.8,227.8$, and $129.5 \mathrm{~kg} / \mathrm{ha}$ increase in yield compared to disk, chisel/disk, and moldboard/disk treatments. Also the number of bolls has increased at the $99 \%$ confidence interval, while increase in boll size has not been significant. Further, morphological measurements showed that plant height significantly changed, while the number of monopodial and sympodial branches did not change significantly. Finally, the results show that no-till system increases soil's water storage capacity

Non ploughing tillage systems has increased in Europe because of the need to reduce costs, to establish winter crops timeously and because of perceived environmental benefits. However, the main objective of the use of non- ploughing tillage is to reduce the costs of production whilst maintaining or increasing yields. Reduced costs take the form of savings of time and machinery. Thus there should be fewer or faster cultivation passes at a shallower depth than under normal ploughing, giving a minimum tillage system. Alternatively, cultivations can be avoided altogether by direct drilling. Environmental benefits of these systems include reductions in soil erosion, nitrate leaching and fuel use, increased soil organic matter and improved soil structure (Bruce Ball, Ian Bingham., 2003). 
No-tillage farming systems or no-till, as an aspect of conservation farming, are actively promoted internationally to conserve soils and by this, ensure food security, biodiversity and water conservation. Instead of tilling before seeding, seeds are deposited directly into untilled soil by opening a narrow slot trench or band. No-till can significantly reduce soil erosion and conserve water in the soils. This is regarded as a basis for higher and more stable crop yields - but science shows that this is not necessarily true (Ginigaddara ,n.d.).

According to Obsa Adugna (2019) Soil tillage affects the sustainable use of soil resources through its influence on soil properties. Proper use of tillage can improve soil related constraints, while improper tillage may cause a range of undesirable processes. Conservation tillage like no tillage had been reported to improve the properties of the soil. Thus, the study had been carried out at Assosa Agricultural research center to evaluate the effects of tillage and cropping system on soil physical properties and in situ moisture conservation. Eighteen experimental runoff plots of $8 \mathrm{~m}$ long and $3 \mathrm{~m}$ wide each were framed with corrugated iron sheets. The experimental design used was randomized complete block design (RCBD) with six treatment in factorial combinations vis-à-vis three cropping systems (sole maize, sole soya bean and intercropping of maize with soya bean), with tillage system (minimum tillage and conventional tillage), that were replicated three times. The bulk density under conventional tillage was declined by $0.3 \mathrm{~g} / \mathrm{cm} 3,0.3 \mathrm{~g} / \mathrm{cm} 3$ and $0.23 \mathrm{~g} / \mathrm{cm} 3$ and the in situ-water retained under conventional tillage was declined by $9.83 \%(18 \mathrm{~mm}), 11.3 \%(21 \mathrm{~mm})$ and $7.76 \%(14.63 \mathrm{~mm})$ as compared to no tillage with mulch treatments for maize, soya bean and maize-soya bean intercropping respectively. These finding illustrated that the water retention capacity of no-tillage with mulch (conservation agriculture) than conventional tillage.

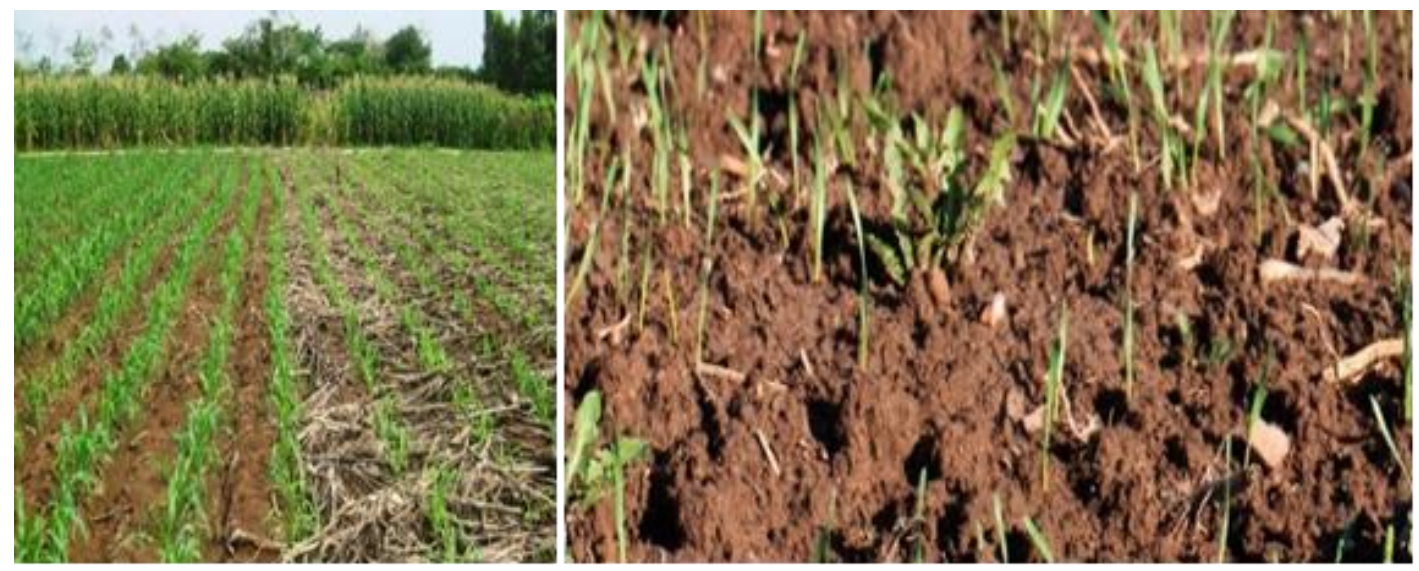

Figure1. Zero tillage (source: Ginigaddara)

\subsubsection{Reduce tillage practice}

Ten to fifteen centimeters long stubble remains on the field after harvest (25 May-1 June). Straw and ears are removed from the plot at harvest. Around 15 July, deep ploughing $(25-30 \mathrm{~cm})$ combined with harrowing $(5-8 \mathrm{~cm})$ is done. Winter wheat is sown around 5 October. This practice thus involves only one ploughing operation instead of two as under CT (Ke Jin, 2007).

According to Stank Tarkowska, et al,2018).on title of Effects of reduced and traditional tillage on soil properties and diversity of diatoms under winter wheat. On the treatment of two different tillage systems: traditional (inversion) tillage (TT) and reduced (non-inversion) tillage (RT). The soil properties: chemical (soil organic carbon, $\mathrm{pH}$, available $\mathrm{P}, \mathrm{K}, \mathrm{Mg}$ ), physical (soil bulk density, water content, stability in water), and biological were measured on samples collected throughout the growing season and at harvest. Soil organic carbon content, water content and bulk density in the 0-5 and 5-10 $\mathrm{cm}$ layers were greater in reduced tillage than in traditional tillage. Wheat yields were positively correlated with precipitation, soil water content and soil organic carbon, and negatively correlated with readily. Accumulations of SOC at the $0-5$ and $5-10 \mathrm{~cm}$ depths were significantly greater by 25 and $7 \%$, respectively under RT than under TT. Depeer.

According to (Mitchal $\mathrm{J}$,et al,2004) Tillage operations in vegetable production typically represent considerable time, energy, equipment, and labor costs that often comprise more than 25 percent of overall pre harvest production budgets. In an effort to control costs and optimize soil management, a wide range of reduced-tillage, or minimum- tillage, production systems for vegetables $h$ is effective. 
Reduced tillage or minimum-tillage alternatives were developed and successfully used to produce a wide range of vegetable crops in the Central and Salinas Valleys. Development of these systems has been stimulated primarily by the desire to reduce production costs and to decrease the time needed for tilling between crops or for incorporating a winter-grown cover crop (Mitchal J, et al,2004).

Reduced tillage is any farming practice which involves less cultivation than used in conventional fallowing. The aim of this system is to minimize soil disturbance, while at the same time achieving a viable seedbed for crop growth. As with no-tillage systems, weeds and diseases are usually controlled with herbicides and grazing. Crop residues are usually burnt and or incorporated into the soil. There are three different types of reducing tillage: reduced cultivation, direct drilling and minimum tillage. Reduced cultivation involves grazing of crop stubble and weed growth after harvest followed by seedbed preparation which includes only one cultivation followed by an application of a contact herbicide before or after sowing. Direct drilling involves no cultivation prior to sowing directly into undisturbed soil; stubbles from the previous crop and subsequent weed growth are removed by grazing during the fallow and the stubble remaining is usually burnt after the seasonal break of rain; the fallow is sprayed with a contact herbicide prior to sowing. Minimum tillage involves the retention of stubble and most of the weeds are controlled with herbicides during the fallow and one mechanical cultivation (Prem et al., 2017).

\subsubsection{Conventional tillage practice}

According to Kovac et al. (2005) on title of the effect of soil conservation tillage on soil moisture dynamics under single cropping and crop rotation in Haplic chernozems. During 1993-1995 the effect of conventional tillage, reduced till, mulch till and no-till technology on soil moisture dynamics has been studied in field experiment on Haplic chernozems near Piestany. The tillage treatments were evaluated under a single cropping of maize and spring barley - common peas - winter wheat crop rotation. Soil samples for gravimetric determination of moisture content were collected from six layers up to $0.8 \mathrm{~m}$, three times per year (April-July). The soil moisture was highly significantly influenced in order of importance by date of sampling, year, growing crops, tillage treatments, soil layer and by interactions. The soil under conventional tillage had significantly higher moisture content than tested reduced till, mulch till and no-till treatments. The significant influence of maize stand on better soil humidity condition $(16.35 \%$ ) in comparison to crops grown in a crop rotation (in average $14.10 \%$ ) has been ascertained.

According to Tigist Oicha et al. (2010) on title with Short-term effects of conservation tillage on soil (Vertisol) and crop (teff, Eragrostis tef) attributes in the northern Ethiopian highlands. The treatments were permanent bed (PB), terwah (TERW) and conventional tillage (TRAD). Soil organic matter (SOM) was significantly higher in PB (2.49\%) compared to TRAD $(2.33 \%)$ and TERW $(2.36 \%)$. Although aggregate stability of PB (0.94) was higher than TRAD (0.83), PB had larger macro porosity $(0.07)$ and higher soil water storage compared to the other treatments. Yield, biomass and plant height of teff were significantly higher in TRAD than PB.

Traditional, or conventional, tillage refers to the sequence of operations "most commonly or historically used in a given field to prepare a seedbed and produce a given crop (MWPS 2000; ASAE 2005). Conventional tillage, which varies widely among regions, has been defined by the Conservation Technology Information Center (CTIC 2002) as incorporating most crop residue and leaving less than 30 percent of the surface covered by residue after planting.Created by the National Association of Resource Conservation Districts as a nonprofit organization in West Lafayette, Indiana, to promote the adoption of conservation practices (Owens 2001), The CTIC has been an important national source of information on tillage systems, and its biennial tillage surveys have tracked tillage (Gesellschaftfiir et al., 2003).

According to Bisrat et al. (2015) on title of Evaluation of Conservation Tillage Techniques for Maize Production in the Central Rift Valley of Ethiopia. Conservation tillage as an approach to reduce surface runoff and soil degradation and reduced tillage systems may offer a compromise solution. The objective of the study is to test different conservation tillage techniques and evaluate the impacts of the system on conserving water, labor requirement for pre and post planting, soil physicochemical properties, plant growth and yield. The experiment was conducted in a semi-arid area in the central Rift Valley of Ethiopia during 2012 and 2013 cropping seasons. The different planting methods used as treatments were: ripping with manual planting, conventional tillage involving two passes with animal drawn 
moldboard plow, ripping once with ripping attached row planter, pitting and no-tillage with hand pushed jab planter were evaluated using Melkassa II maize variety. Results have been compared with conventional tillage involving two passes with animal drawn moldboard plow. Soil chemical properties monitored before and after tillage to a depth of $15 \mathrm{~cm}$ though were not statistically significant. The study showed that the performance of ripping followed by manual planting tillage system was superior to the other four tillage treatments in tillage time, and weeding time, except the conventional tillage system. Ripping once and planting is a better in saving tillage time, avoiding delayed planting and drudgery to animals and human beings compared to reduced tillage system in areas where the rainfall pattern is erratic in nature as rift valley. It is also recommended that the right time of planting with uniform seed Placement can be achieved if there is an efficient row planter that can be attached to the ripper.

On title of In Situ moisture conservation through tillage Practices. It is becoming increasingly clear that the challenge of feeding tomorrow's population is to a large extend about improving productivity of water within present land use, as new arable land is relatively limited. To increase the moisture availability to the agricultural crops, it is necessary to adopt in-situ moisture conservation techniques in addition to the large-scale soil and moisture conservation and water harvesting structures in the watershed. There are very much tillage techniques are used to conserve the moisture in the field for proper growth of crops. Tested tillage techniques are subsoiling, open and tied ridges, no till, and conventional tillage. Performance of the tillage techniques varied with seasonal rainfall distribution and intensity and land slope gradient. Tied and open ridge increased seasonal root zone soil moisture 15$24 \%$. Subsoiling slightly (3\%) increased and no till slightly decreased soil moisture but were not statistically different from conventional tillage. Tied ridge and no till significantly reduced seasonal soil loss by up to $11 \mathrm{Mg}$ ha-1 during seasons with moderate intensity storms, but during a season with high intensity storms tied ridge on over 9\% slope gradient increased soil loss (up to $35 \mathrm{Mg}$ ha-1). The increased soil disturbance of subsoiling led to higher soil loss rates (up to $32 \mathrm{Mg}$ ha-1) than conventional tillage during all seasons. Subsoiling was moderately effective for improving soil moisture and reducing runoff. The soil under conventional tillage had significantly higher moisture content than tested reduced till, mulch till and no-till treatments (Prem et al., 2017).

According to Tolossa D. et al. (2007).Based on the title Effect of tillage system and nitrogen fertilization on yield and yield components of maize in western Ethiopia Three tillage systems (MTRR $=$ minimum tillage with residue retention, MTRV minimum tillage with residue removal and CT $=$ conventional tillage) and three $\mathrm{N}$ levels (the recommended rate and 25\% less and 25\% more than this rate) were combined in factorial arrangement with three replications.

The recorded grain yield in the experiments ranged from 4649 to $8030 \mathrm{~kg}$ ha-1 with an average of 6104 $\mathrm{kg}$ ha-1. Grain yield was positively and significantly correlated with several yield components, especially total biomass yield and thousand seed weight. The application of $\mathrm{N}$ increased grain yield regardless of tillage system and the recommended fertilization rate of $92 \mathrm{~kg} \mathrm{~N}$ ha- 1 for conventional tilled maize was also found adequate for minimum tilled maize. These results proved that MTRR can be introduced successfully in western Ethiopia.

According to ( Chunjian Tan, et al., 2015) On Title Effects of Long-term Conservation Tillage on Soil Nutrients in Sloping Fields in Regions Characterized by Water and Wind Erosion. Conservation tillage is commonly used in regions affected by water and wind erosion. To understand the effects of conservation tillage on soil nutrients and yield, a long-term experiment was set up in a region affected by water and wind erosion on the Loess Plateau. The treatments used were traditional tillage (CK), no tillage (NT), straw mulching (SM), plastic-film mulching (PM), ridging and plastic-film mulching (RPM) and intercropping (In). Our results demonstrate that the available nutrients in soils subjected to non-traditional tillage treatments decreased during the first several years and then remained stable over the las several years of the experiment. The soil organic matter and total nitrogen content increased gradually over 6 years in all treatments except CK. The nutrient content of soils subjected to conservative tillage methods, such as NT and SM, were significantly higher than those in soils under the CK treatment. Straw mulching and film mulching effectively reduced an observed decrease in soybean yield. Over the final 6 years of the experiment, soybean yields followed the trend RPM > PM $>\mathrm{SM}>\mathrm{NT}>\mathrm{CK}>\mathrm{In}$. This trend has implications for controlling soil erosion and preventing non-point source pollution in sloping fields by sacrificing some food production. 


\subsubsection{Frequency tillage practice}

According Tenaw Workayehu (2010) On the Title Effect of Plowing Frequency and Weeding Methods on Weeds and Grain Yield of Wheat at Arsi Negelle, Ethiopia. Five tillage practices (zero, one, two, three and four times tillage) as main plot and four weed control methods (Duplosan sprayed at 2.51 ha1, Duplosan plus one hand weeding at 30 days after emergence (DAE); one and two hand weeding at 30 , and 30 and $60 \mathrm{DAE}$, respectively) as subplots were arranged in split plot design with three replications. Broadleaf weeds comprised $73 \%$ of the total weed population in the experimental plots. Effect of tillage and weed control was dependent on year. Increased frequency of tillage reduced weed infestation. Weed density in zero-till and three times plowing was 78 and 35\%, respectively, more than four times. Weed. Generally, four times plowing significantly reduced weed infestation and increased wheat grain yield with considerable economic benefit.

\subsubsection{Contour tillage practice}

According to Farahani et al. (2016) on the title of Effects of Contour Farming on Runoff and Soil Erosion Reduction. The purpose of contour farming is to reduce runoff and soil erosion on mild slopes. This practice can also increase crop yield through the soil moisture retention in arid and semi- arid regions. Results showed contour cultivation reduced the annual runoff as $10 \%$ in compared with cultivation perpendicular to the slope. Also cultivation and planting along contour lines in comparison with cultivation and planting downwards the slop reduced soil losses and water losses as 49.5 and 32\%, respectively. Although contour farming reduces runoff and soil erosion largely, but when it's combined with other conservation tillage such as no-tillage or minimum tillage can be more effective. Contour farming on permanent raised beds combined with residue retained on the soil surface is suggested according the results of previous studies as the best practice on mild slopes.

Table1. Effect of management and conservation practices on erosion losses under annual crops (Bertoni et al., 1972).

\begin{tabular}{|l|l|l|}
\hline Cultivation and Planting Practices & Soil loss (t/ha) & Water loss( of rainfall) \\
\hline Down slop & 26.1 & 6.9 \\
\hline Along Contours & 13.2 & 4.7 \\
\hline Contours + alternation with pasture & 9.8 & 4.8 \\
\hline Contours + bands of sugarcane & 2.5 & 1.8 \\
\hline
\end{tabular}

According to Traore et al. (2004) On title of contoured ridge-tillage increases cereal yields and carbon sequestration In Mali. In southern Mali, under a semi-arid climate, contour-ridged tillage can reduce soil erosion and substantially increase the infiltration of rain water resulting in increased growth of the crops and the trees associated with the crops in the traditiona 1 farmed landscapes. Permanent contour ridges, covered with perennial grasses, are maintained in the fields, thus giving the main frame for drawing the contour lines. The farmers follow those permanent ridges when dressing the annual contour ridges for their crops. Contoured ridges increased infiltration of rain water by up to $10 \%$ of the total annual rainfall $(800 \mathrm{~mm})$, even in fields with a gentle slope between 1 to $2 \%$. Crop growth was improved. Cereal yields (millet, sorghum and maize) were increased on average by $30 \%$, and over $50 \%$ during the dry years. The increased infiltration replenished water stocks in the subsoil and increased the growth of existing trees (Vitellaria paradoxa and other valued species) in the traditional cultivated tree parks. This cropping technique facilitated the germination of seeds from those trees and the establishment of seedlings. The ligneous bio-mass was increased, contributing to carbon sequestration. Therefore, contour-ridge-tillage, increasing cereal yields and carbon stocks in the soil, promotes a more sustainable small-scale farming in semi-arid Western Africa.

Contour farming system Contour farming involves aligning plants rows and tillage lines at right angles to normal flow of runoff. It creates detention storage in the soil surface horizon and slows down the runoff, thus giving the water time to infiltrate into the soil (FAO, 1993). The contour bunds are earth banks 1.5 to $2.0 \mathrm{~m}$ wide, forming buffer strips at 10 to $20 \mathrm{~m}$ intervals, and are important for the functioning of the technology. The effectiveness of contour farming for water and soil conservation depends on the design of the systems, but also on soil, climate, and slope aspect and land use of the individual fields (Prem et al., 2017). 


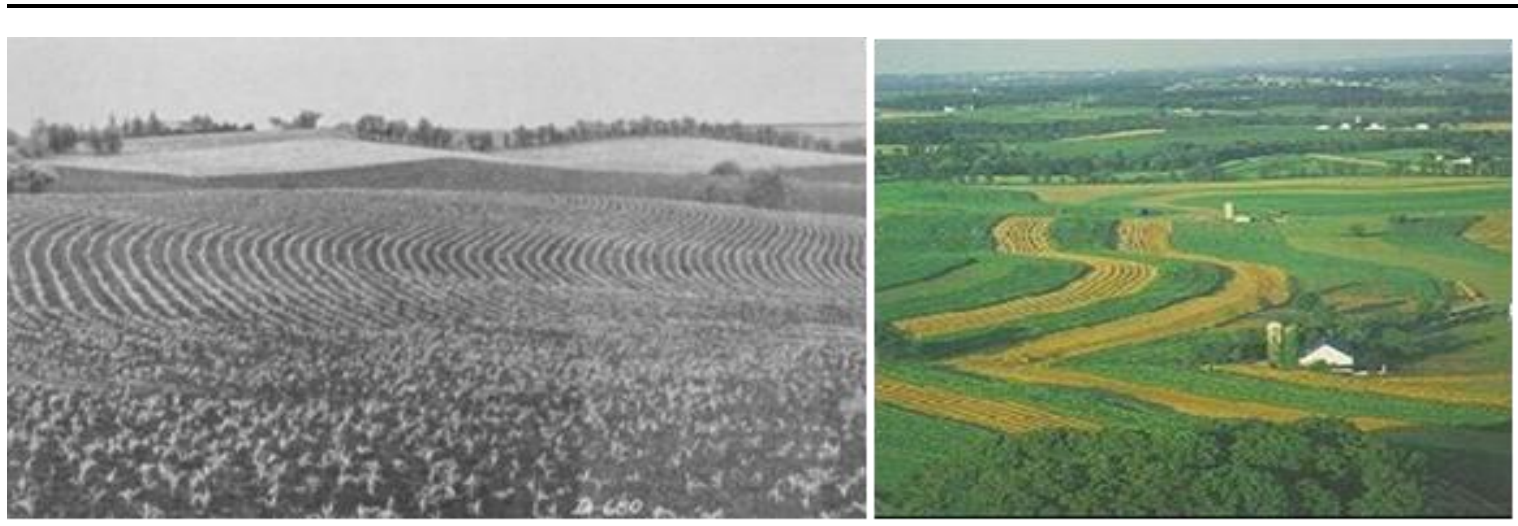

Figure2. Contour farming for soil and water conservation (Van, 1940)

\subsubsection{Conservation tillage practice}

According to Sitaula et al. (2017) Conservation tillage is expected to have a positive effect on soil physical properties, soil Carbon (C) storage, while reducing fuel, labor and machinery costs. The treatment were the short-term effects of reduced (RT) and no tillage (NT) on N2O emission dynamics, soil structure and the economics of cereal production, as compared with conventional tillage (CT). In the much wetter 2014, N2O emission were in the order of CT > RT > NT, while in the drier 2015, the order was RT > CT > NT. NT resulted in eco- nomically inacceptable returns, due to the increased costs of weed control and low yields in both years. Therefore, RT could potentially provide agronomic and environ- mental benefits in crop production. Conservation tillage is defined as any tillage or planting system in which at least $30 \%$ of the soil surface is covered by plant residue after planting to reduce water and wind erosion (Prem et al., 2017).

Conservation tillage (CT) has been used recently in California to describe crop production systems that reduce tillage even more than minimum tillage. Most CT systems are based on one of three planting systems that reduce soil disturbance: no-till, ridge-till, and strip-till. In no-till, or zero-till, the only tillage that is used is the soil disturbance in a narrow slot created by coulters or seed openers. The soil surface is generally left undisturbed except at the time of planting. Ridge-till is a reduced- disturbance planting system in which crops are planted and grown on ridges formed during the previous growing season and by shallow, in-season cultivation equipment. Ridge-till planters sweep away or shear off residues and soil in the seed line but do not disturb much of the inter row soil surface (Mitchal J. et al ,2004).

According to Matecka et al (2012) conventional tillage, reduced tillage, and no-tillage. Continuous cultivation for 7 consecutive years by reduced tillage and no-tillage led to changes in the physical properties of the surface soil layer $(0-5 \mathrm{~cm})$. At the stem elongation growth stage of spring barley, conservation tillage systems resulted in a higher water content and bulk density in relation to conventional tillage. Conservation soil tillage resulted in decreased penetration resistance in the $0-10$ $\mathrm{cm}$ layer, as compared with conventional tillage. Reduced tillage and no- tillage favored the surface accumulation of organic $\mathrm{C}$ and total $\mathrm{N}$ in the soil, as well as that of available $\mathrm{K}$ and $\mathrm{Mg}$. Our results suggest that conservation tillage systems lead to progressive improvement in soil nutrient status, but have little or no eff ect on crop yield. Only the no-tillage system had a negative effect on yield of spring barley, by $6.8 \%$ in comparison with conventional tillage (Matecka et al., 2012).

The highest C-to-N ratio was obtained at the top soil layer $(0-5 \mathrm{~cm})$ of the NT plots, but no signifi can't diff erence was observed between NT and RT. Th e diff erence in soil C-to-N ratios between tillage systems was not significant at the 10- 20 but in dry years, greater water content is found after NT (Matecka et al., 2012).

Table2. Volumetric water content and soil bulk density as affected by tillage system (mean of 2004-2006). Source: (Matecka et al., 2012).

\begin{tabular}{|c|c|c|c|c|}
\hline \multirow{3}{*}{ Tillage system } & \multicolumn{2}{|c|}{ Volumetric water content (\%) } & \multicolumn{2}{|c|}{ Bulk density $\left(\mathrm{Mg} \mathrm{m}^{-3}\right)$} \\
\hline & \multicolumn{4}{|c|}{ Soil layer $(\mathrm{cm})$} \\
\hline & $0-5$ & $10-20$ & $0-5$ & $10-20$ \\
\hline CT & $12.2 \mathrm{c}$ & $16.4 \mathrm{~b}$ & $1.39 \mathrm{c}$ & 1.59 \\
\hline RT & $15.3 \mathrm{~b}$ & $18.0 \mathrm{a}$ & $1.54 \mathrm{~b}$ & 1.62 \\
\hline
\end{tabular}




\begin{tabular}{|l|l|l|l|l|}
\hline \multicolumn{7}{|l|}{} & \multicolumn{1}{l|}{} \\
\hline NT & $17.6 \mathrm{~b}$ & $18.9 \mathrm{a}$ & $1.69 \mathrm{a}$ & 1.64 \\
\hline Tillage system & $1.61^{* *}$ & $1.32^{* *}$ & $0.075^{*}$ & NS \\
\hline
\end{tabular}

NS : not significant; $* * p<0.01 \mathrm{CT}, \mathrm{RT}$ and NT are Conventional, reduce and no tillage respectively.

According to Tabiehzad et al. (2017) the effects of different tillage methods under wheat-corn twocourse rotation system on some soil aggregation properties and yields were investigated. Experiment was laid out in a split plot design with three replications during four crop years. Subsoiler, moldboard, sweep and chisel as main plots and rotary tiller and disc harrow as sub-plots have been used in this study. The results showed that tillage methods were significant at $(\mathrm{P}<0.01)$ as regards crop yields, and the highest yields as 6249 and $11720 \mathrm{~kg} / \mathrm{ha}$ for wheat and 9891 and $73080 \mathrm{~kg} / \mathrm{ha}$ for corn grain and biomass were produced in subsoiler treatment, respectively. Subsoiler rotary tiller treatment was significant at $(\mathrm{P}<0.05)$ with $2.063 \mathrm{~mm}$ as to mean weight diameter (MWD) value. The sub soiler and chisel were statistically in the same group with regard of water stable aggregates (WSA) value, and it was significant at $(\mathrm{P}<0.05)$ with $67,83 \%$. Bulk density, total porosity and air porosity values were significant at $(\mathrm{P}<0.01)$, and $1.38 \mathrm{grcm}-3,51.2 \%$ and $12.5 \%$ values were determined in rotary tiller application, respectively. Field capacity (FC) and permanent wilting point (PWP) were significant at $(\mathrm{P}<0.05)$ and $(\mathrm{P}<0.01)$ with $31.89 \%$ and $17.21 \%$ values in the chisel treatment, respectively. Crop yields and positive effects on the physical properties were considered subsoiler rotary tiller treatment was the most successful, and it was followed by chisel rotary tiller treatment according to four-year study results (Tabiehzad et al., 2017).

According to Tan, et al (2015) Conservation tillage is commonly used in regions affected by water and wind erosion. To understand the effects of conservation tillage on soil nutrients and yield, a long-term experiment was set up in a region affected by water and wind erosion on the Loess Plateau. The treatments used were traditional tillage $(\mathrm{CK})$, no tillage (NT), straw mulching (SM), plastic-film mulching (PM), ridging and plastic-film mulching (RPM) and intercropping (In). Our results demonstrate that the available nutrients in soils subjected to non-traditional tillage treatments decreased during the first several years and then remained stable over the last several years of the experiment. The soil organic matter and total nitrogen content increased gradually over 6 years in all treatments except CK. The nutrient content of soils subjected to conservative tillage methods, such as NT and SM, were significantly higher than those in soils under the CK treatment. Straw mulching and film mulching effectively reduced an observed decrease in soybean yield. Over the final 6 years of the experiment, soybean yields followed the trend RPM > PM > SM > NT > CK > In. This trend has implications for controlling soil erosion and preventing non-point source pollution in sloping fields by sacrificing some food production.

On title of tillage and crop management effects on air, water and soil quality in california. Conservation tillage (CT) has become an important management tool in production systems throughout the world. The term "conservation tillage" has been defined in various ways over the past 70 years, depending on the region in which it has been practiced. The USDA Natural Resources Conservation Service (formerly the Soil Conservation Service) defines CT as maintaining a minimum of 30 percent soil cover with crop residues after planting. The collective advantages of CT correspond to widespread adoption. It has been estimated that in 2001-2002, 72 million hectares globally were under no-till, a form of CT in which no soil disturbance occurs from the harvest of one crop to the planting of the next (Horwath ,et al,2008).

According to Tesfahunegn (2012) with title of Effect of Tillage and Fertilizer Practices on Sorghum Production in Abergelle Area, Northern Ethiopia. Sorghum (Sorghum bicolor L. Moench) production is mainly constrained by soil water and nutrient deficits in northern Ethiopia. The aim of this research was to evaluate the effects of tillage and fertilizer practices on productivity of two sorghum varieties in Abergelle area, northern Ethiopia. The experimental design was split-plot design. The main-plot treatments included five tillage practices. These were shilshalo (traditional ridge without ties) for broadcasted planting (SBP), tied-ridging at planting (TR0WAP), tied-ridging at four weeks after planting (TR4WAP), zero tillage (ZT), and shilshalo for row planting (SRP). Two fertilizer rates of nitrogen $(\mathrm{N})$ and phosphorus $(\mathrm{P})$, as0-0 N-P ha ${ }^{-1}$ (without fertilizer, F1) and 32-10 kg N-P ha ${ }^{-1}$ (with fertilizer, F2) treatments.the increment of yield and yield components due to the tied-ridging and fertilizer interaction effects were higher sorghum crop yield due to TR0WAP interaction with F2 was $1.45 \mathrm{t} \mathrm{ha}^{-1}$. Suitable time of tied-ridging integrated with proper rate of fertilizer should be adopted for effective increase of crop production in the semi-arid areas of northern Ethiopia such as the Abergelle. 
According to Khursheed et al., 2019) On title of Conservation tillage impacts on soil physical conditions. Conservation tillage improves soil aggregate stability that enhances nutrient retention and reduces soil erosion thereby contributing to soil fertility and mediates air permeability, water infiltration, and nutrient cycling. CT is particularly important in arid and semi-arid zones, where water is the limiting factor for crop development and thus correct management of crop residues is essential to achieve sustainable yields. CT with mulch improved the soil porosity, soil structure, and water transmission in alfisols and more continuous pore system because of earthworm activity, long root channels etc.

\subsection{Effects of Tillage on Soil Properties and Crop Production}

On title of effects of various long-term tillage systems on some chemical and biological properties of soil. One of the directions of actions limiting the occurrence in soil environments of unfavorable phenomena accompanying conventional tillage is the introduction of reduced tillage, even total abandonment of cultivation operations. The objective of the performed investigation was to compare the impact of conventional tillage, reduced tillage, and no- tillage on some soil chemical (Corg., total $\mathrm{N}, \mathrm{pH}$ ) and microbiological (total bacterial counts, numbers of oligotrophs, copiotrophs and fungi, activity of dehydrogenases and acid phosphatase) properties (Swedrzynska et al, .2013).

Tillage treatments directly or indirectly influence soil hydraulic properties such as water infiltration, hydraulic conductivity, and water retention which determine the ability of the soil to capture and store water through precipitation or irrigation. Tillage changes flow path and rate of water by rearranging aggregate size distribution. Therefore, tillage systems conserving water in soil are important for plant growth under arid and semiarid conditions (Blanco, 2017).

The main effect of tillage on yield was not significant. Mean stover yield was also increased with straw application. Mean soil water throughout the season was nearly $20 \%$ more with tied-ridging than with other tillage practices and about $16 \%$ more with $3 \mathrm{mg}$ ha straw applied as compared to no straw applied. Grain produced per unit of water used 1 increased linearly with straw application rate and was less for zero tillage and for tied-ridging or conventional tillage. Tied-ridging is the most promising tillage practice and ground cover with crop residues is necessary to achieve acceptable yield with zero tillage (Tewodrose Mesfine et al., 2005).

\subsubsection{Positive Effect of Tillage on Soil Properties and Crop Production}

The main effect of tillage on yield was not significant. In directly influence soil hydraulic properties such as water infiltration, hydraulic conductivity, and water retention which determine the ability of the soil to capture and store water through precipitation or irrigation Tillage practices showed positive effects on soil properties and crop yields. Mean stover yield was also increased with straw application. Mean soil water throughout the season was nearly $20 \%$ more with tied-ridging than with other tillage practices and about $16 \%$ more with $3 \mathrm{mg}$ ha straw applied as compared to no straw applied. Grain produced per unit of water used 1 increased linearly with straw application rate and was less for zero tillage and for tied-ridging or conventional tillage. Tied-ridging is the most promising tillage practice and ground cover with crop residues is necessary to achieve acceptable yield with zero tillage (Tewodrose Mesfine et al., 2005).

Tillage practices affect both the physical and chemical properties and have consequences for soil biological activity and soil functions. High correlations were obtained between soil parameters (SOC) and SWC, DB, and RDC (Table 6). These correlations demonstrate the high sensitivity of the studied properties to changes in soil management. WY was found to be correlated with some soil properties and weather conditions, especially precipitation. The WY showed positive correlations with SOC $(0.445$ TT, 0.509 RT), SWC (0.671 TT, 0.542 RT) (Stanek et al., 2018).

\begin{tabular}{|c|c|c|c|c|c|}
\hline \multirow{3}{*}{ Tillage system } & & Years & & & \multirow[b]{2}{*}{ Mean } \\
\hline & 2003 & 2004 & 2005 & 2006 & \\
\hline & \multicolumn{5}{|c|}{ Grain Yield (t/ha) } \\
\hline $\mathrm{CT}$ & $5.89 a$ & $6.28 \mathrm{a}$ & 5.91 & $4.95 \mathrm{a}$ & $5.76 a$ \\
\hline RT & $5.46 \mathrm{~b}$ & $6.12 \mathrm{a}$ & 6.09 & $5.02 \mathrm{a}$ & $5.67 \mathrm{a}$ \\
\hline NT & $5.55 b$ & $5.59 \mathrm{~b}$ & 5.88 & $4.54 b$ & $5.39 \mathrm{~b}$ \\
\hline Mean & 5.63 & 6.00 & 5.96 & 4.84 & - \\
\hline LSD & $0.234 *$ & $0.323^{*}$ & $\mathrm{NS}$ & $0.282 *$ & $0.231 *$ \\
\hline
\end{tabular}

Effects of Different tillage in crop production. Source ; (Małecka, et al, 2012). 


\subsubsection{Negative Effect of Tillage on Crop Production}

Frequent tillage when producers use unnecessary tillage, more serious problems begin to occur. Without a break from tillage, a total breakdown of soil structure is possible. Soil organisms can be affected, bringing microbial activity to a halt. Soil pores are closed, imposing severe limitations on infiltration and increasing runoff.

Negative responses to RT and NT may also result from a smaller uptake of nitrogen by plants

Negative responses to RT and NT may also result from a smaller uptake of nitrogen by plants caused by its immobilization in the soil, lower temperatures in the spring period, higher soil bulk density, and penetration resistance of the soil impeding the development of the plant root system. reductions in soil tillage lead primarily to a decrease in plantdensity in the tillering and in the number of ears per square meter, and, in consequence, to a decrease in cereal yield (Małecka, et al,2012).

There may even be some initial loss of productivity with moderate levels of erosion. With frequent tillage sustained over a couple years, topsoil loss begins to exceed replacement. In time, the soil is in danger of yield setbacks due to organic matter and nutrient loss as well as the damage done to the soil's physical properties. Conservation soil tillage resulted in decreased penetration resistance in the $0-10 \mathrm{~cm}$ layer, as compared with conventional tillage (Stanek, et al,2018).

\section{CONCLUSiON}

Tillage has been an important aspect of technological development in the evolution of agriculture, in particular in food production. The objectives of tilling the soil include seedbed preparation, water and soil conservation and weed control. Tillage has various physical, chemical and biological effects on the soil both beneficial and degrading, depending on the appropriateness or otherwise of the methods used. The physical effects such as aggregate- stability, infiltration rate, soil and water conservation, in particular, have direct influence on soil productivity and sustainability. different tillage practices showed that they influenced soil physical and chemical properties along with the improvement of SOM status under different crop production. Tillage have also its own positive and negative influence on residue incorporation conserved moisture in the soil and other soil properties like, soil $\mathrm{PH}$, soil organisms, water holding capacity, soil structure and bulk density.

\section{REFERENCES}

[1] Abu-Hamdeh, N. H. 2004. The effect of tillage treatments on soil water holding capacity and on soil physical properties. 13th International Soil Conservation Organization Conference, (669), 1-6.

[2] Adugna, O. ,2019. Effects of tillage practices and cropping system on soil physical properties and in-situ water conservation in clay loam of Assosa, Ethiopia. 7(9), 794-802.

[3] Barron, J., Rockström, J., Gichuki, F., and Hatibu, N., 2003. Dry spell analysis and maize yields for two semi-arid locations in east Africa, Agric. For. Met. 117:23-37.

[4] Bisrat Getnet, Kebede, L., \& Kim, H. K. 2015. Evaluation of Conservation Tillage Techniques for Maize Production in the Central Rift Valley of Ethiopia. Ethiopian Journal of Agricultural Sciences, 25(2), 47-58.

[5] Blanco Canqui ,H., B.J. Wienhold, V.L. Jin, M.R. Schmer, L.C. Kibet, 2017. Long-term tillage impact on soil hydraulic properties, Soil and Tillage Research, 170 ,38- 42.

[6] Bruce Ball, Ian Bingham ,2003. Minimum tillage .Technical Note.

[7] Chawala, K., \& Kahlon, M. (2018). Effect of land management practices on soil moisture retention. Journal of Applied and Natural Science, 10(1), 386-392.

[8] Dangolani, S. K., \& Narob, M. C. 2013. The effect of four types of tillage operations on soil moisture and morphology and performance of three varieties of cotton PhD Student, Tajik Agrarian University. European Journal of Experimental Biology, 3(1), 694-698.

[9] Eric Scopela, François Tardieub, Gregory Edmeadesc, and Michel Sebillotted 2001.Effects of Conservation Tillage on Water Supply and Rainfed Maize Production in Semiarid Zones of West-Central Mexico. Paris, France.

[10] FAO, 1993. Soil tillage in Africa: needs and challenges. FAO soils bulletin 69. Soil Resources, Management and Conservation Service,Farahani, S., Soheili-Fard, F., \& Amin Asoodar, M. 2016. Effects of contour farming on runoff and soil erosion reduction. Elixir Agriculture, 101,44089-44093. Retrieved from https://www.researchgate.net/publication/312054716.

[11] Gebreegziabher T, Nyssen J, Govaerts B, Fekadu G, Mintesinot B, Mitiku H, Deckers J.2009.Contour furrows for in-situ soil and water conservation, Tigray, Northern Ethiopia. Soil Tillage Research 103, $257-264$.

[12] Gesellschaftfiir, D., Zusammenarbeit, T., \& Gmbh, G. T. Z. .2003. Conservation Tillage, No- Tillage And. 181-19. 
[13] Ginigaddara, G. A. S. (n.d.). Zero Tillage / Minimum Tillage. 1-32.Horwath, W. R., Mitchell, J. P., \& Six, J. W. (2008). Tillage and Crop Management Effects on Air, Water and Soil Quality in California. Tillage and Crop Management Effects on Air,Water and Soil Quality in California, (September). https://doi.org/10.3733/ucanr.8 331

[14] J.K. Ward, F.J. Arriaga, K.S. Balkcom, T.S. Kornecki, J.S. Bergtold, \& A.J. Price and R.L. Raper. 2013. Effects of Conservation Systems on Soil Moisture and Productivity in Cotton. 0300(06). https://doi.org/10.13031/2013.22261

[15] Khursheed, S., Simmons, C., Sartaj, A., Ali, T., Sk, R., \& Gr, N. .2019. Conservation tillage : impacts on soil physical conditions - an overview. Advances in Plants \& Agriculture Research, 9(2), 342-346. https://doi.org/10.15406/apar.2019.09.00446

[16] Landers, J. N., Rass, G., Freitas, P. L., Basch, G., González, E., S., ... Giupponi, L. 2013. Effects of Zero Tillage (No-Till) Conservation Agriculture on soil physical and biological properties and their contributions to sustainability. Geophysical Research Abstracts, 15(123456789123), 2013 11756. Retrieved from http://meetingorganizer.cope rnicus.org/EGU2013/EGU2013-11756-4.pdf

[17] Małecka, I., Blecharczyk, A., Sawinska, Z., \& Dobrzeniecki, T. 2012. Th e eff ect of various long-term tillage systems on soil properties and spring barley yield. 36, 217-226. https://doi.org/10.3906/tar-1104-20.

[18] Meryem Kuzucua and Funda Dökmenb. 2015. the effects of tillage on soil water content in dry areas. Gaziantep, Türkiye.

[19] Mitchell, J. P., Pettygrove, G. S., Upadhyaya, S., Shrestha, A., Fry, R., Roy, R. ,Hembree, K. 2009. Classification of Conservation Tillage Practices in California Irrigated Row Crop Systems. Classification of Conservation Tillage Practices in California Irrigated Row Crop Systems, (February). https://doi.org/10.3733/ucanr.8364

[20] Prem, M., Swarnkar, R., Ranjan, P., \& V Baria, A.2017. in Situ Moisture Conservation Through Tillage Practices. Multilogic in Science, 7(23), 131-135.

[21] Sitaula, B. K., Hamid, Č., \& Jasminka, Z. 2017. Effects of tillage practice on soil structure , N 2 O emissions and economics in cereal production under current socio-economic conditions in central Bosnia and Herzegovina. 1-22.

[22] Stanek-Tarkowska, J., Czyz, E. A., Dexter, A. R., \& Sławiński, C. 2018. Effects of reduced and traditional tillage on soil properties and diversity of diatoms under winter wheat. International Agrophysics, 32(3), 403409. https://doi.org/10.1515/intag-2017-0016

[23] Strudley, M.W., Green, TR., Ascough, J.C., 2008. Tillage effects on soil hydraulic properties in space and time: State of the science, Soil and Tillage Resources, 99:4-48.

[24] Tenaw Workayehu .2010.Effectof plowing Frequency and weed method on weed and grain yield of wheat.East Africa Journal of Sciences.4,114-122.

[25] Tesfahunegn, G. 2012. Effect of Tillage and Fertilizer Practices on Sorghum Production in Abergelle Area, Northern Ethiopia. Momona Ethiopian Journal of Science, 4(2), 52. https://doi.org/10.4314/mejs.v4i2.80116.

[26] Tewodrose Mesfine, Girma Abebe, Abdel-Rahman and M. Al-Tawaha. 2005. Effect of Reduced Tillage and Crop Residue Ground Cover on Yield and Water Use Efficiency of Sorghum (Sorghum bicolor (L.) Moench) Under Semi-Arid Conditions of Ethiopia .Nazreth, Ethiopia.

[27] Tigist Oicha,Wim M.Cornelis,Hubert verplancke,Jan Nyssen,Bran Govaerts,Mintesinot Behailu,Mitiku Haileand Jozef Deckers ,2010.short term effects of conservation tillage on soil (vertisol) and crop (teff ,Eragrostis teff) attributes in The Northern Highlands.149-152.

[28] Tolessa, D., Du Preez, C. C., \& Ceronio, G. M. 2007. Effect of tillage system and nitrogen fertilization on yield and yield components of maize in western ethiopia. South African Journal of Plant and Soil, 24(2), 63-69. https://doi.org/10.1080/02571862.2007.10634783.

Citation: Demsew Bekele, “The Effect of Tillage on Soil Moisture Conservation: A Review." International Journal of Research Studies in Agricultural Sciences (IJRSAS), 2020; 6(10), pp. 30-41, https://doi.org/10.20431/2454-6224.0610004

Copyright: (C) 2020 Authors. This is an open-access article distributed under the terms of the Creative Commons Attribution License, which permits unrestricted use, distribution, and reproduction in any medium, provided the original author and source are credited. 